\title{
Ameliorative potential of Psidium guajava in induced arsenic toxicity in Wistar rats
}

\author{
Manju Roy and Sushovan Roy \\ College of Veterinary Science \& A.H. Anjora, Durg (C.G) 491001 \\ 1. Professor \& Head, Deptt. Of Veterinary Medicine \\ 2. Associate Professor, Deptt. of Public Health \\ *Corresponding author email: dr_sushovan_roy@yahoo.com
}

\begin{abstract}
The study was undertaken to determine the effect of Psidium.guajava leaf extract on arsenic induced biochemical alterations in Wistar rats. Significant $(\mathrm{P}<0.05)$ increased glucose serum urea nitrogen and serum creatinine was observed whereas non significant decrease in total protein, calcium and phosphorus was observed. It is concluded that kidney damage caused by arsenic can be repaired up to some extent by $\mathrm{AEPG}_{50}$.
\end{abstract}

Key words: Arsenic, Biochemical alterations, Psidium guajava, Rat, Toxicity

\section{Introduction}

Arsenic is a naturally occurring element that has been recognized as a human poison since ancient times. Arsenic (As) is a ubiquitous element present in low concentrations in air, soil and water. Higher level of arsenic in ground water are associated with sedimentary deposits derived from volcanic rocks, hence mineral leaching appears to be the source of arsenic concentration (Pandey et al., 2004). Liver and kidney are the organs mainly affected with arsenic intoxication (Roy et al., 2008) Numerous biological materials have been listed for removal of toxic ions from aqueous solution over the last two decades. However, only a limited number of studies have investigated the use of adsorbents derived from biological sources. The study was aimed to test the efficacy of antioxidant effect of Psidium guajava in induced arsenic toxicity in rats.

\section{Material and methods}

Mature leaves of Psidium guajava tree were collected from near by areas of Durg district, India. The leaves were washed thoroughly, shade dried and blended to form a fine powder. Then, $250 \mathrm{~g}$ of dry powder was macerated with one liter of double distilled water for $72 \mathrm{hrs}$ at $30 \pm 4^{\circ} \mathrm{C}$. The extract was filtered to remove particulates and concentrated in water bath at $50^{\circ} \mathrm{C}$. Finally, the concentrated crude aqueous extract was subjected to drying to solid mass (yield 16.6\%) was obtained. The testing samples were prepared by dissolving extract (AEPG) with double distilled water. Eighteen Albino Wistar rats of 10-12 wks old and weighing approximately $150-200 \mathrm{~g}$ were used for this study (after obtaining permission from the institutional Animal Ethics Committee (IAEC) were housed in plastic cages in a $12 \mathrm{hrs}$ dark light cycle with temperature ranging between $25-30^{\circ} \mathrm{C}$ and were provided with standard laboratory animal feed and water. After 15 days of acclimatization, the rats were randomly divided into 3 groups of 6 rats each. Group I served as control and rats in Groups II \& III received arsenic as sodium arsenite (NaAsO2) @ 20mg/kg in drinking water adlib for 45 days. Group III along with arsenic exposure also received aqueous extract of Psidium. Guajava @ 50mg/kg body weight $\left(\mathrm{AEPG}_{50}\right)$ leaves everyday by stomach tube till the end of the experiment.

The rats were anesthetized by light chloroform anesthesia after 45 days. Blood was collected by cardiac puncture for analysis of biochemical parameters. Glucose, total protein, serum urea nitrogen, creatinine was estimated quantitatively using kits of Bayer Company with the help of biochemistry analyzer Robonik ASP 300.

The data on biochemical parameters were analysed employing analysis of variance described by Snedecor and Cochran, (1994).

\section{Results and discussion}

The mean blood glucose level increased significantly with the increase of arsenic dose in comparison to control. In the present study the amelioration effect of AEPG against chronic toxicity of arsenic in goats with special reference to blood glucose was effective. Our results supports the findings of Tseng et al., 2002 who also observed 
Table. 1. Protective effect of Psidium.guajava on biochemical alterations in arsenic induced toxicity in $\mathrm{Wister}$ rats.

\begin{tabular}{llll}
\hline Biochemical parameters & Group I & Group-II & Group-III \\
\hline Glucose $(\mathrm{mg} / \mathrm{dl})$ & $58.32 \pm 0.23$ & $76.39 \pm 0.38^{*}$ & $61.27 \pm 0.44$ \\
Serum total protein $(\mathrm{g} / \mathrm{dl})$ & $6.33 \pm 0.46$ & $5.15 \pm 0.53$ & $6.20 \pm 0.41$ \\
Serum Urea Nitrogen $(\mathrm{mg} / \mathrm{dl})$ & $15.76 \pm 0.27$ & $20.43 \pm 0.34^{*}$ & $16.95 \pm 0.25$ \\
Creatinine $(\mathrm{mg} / \mathrm{dl})$ & $0.83 \pm 0.33$ & $1.21 \pm 0.47^{*}$ & $1.06 \pm 0.35$ \\
Serum calcium $(\mathrm{mg} / \mathrm{dl})$ & $7.24 \pm 0.62$ & $6.42 \pm 0.53$ & $6.87 \pm 0.60$ \\
Serum phosphorus $(\mathrm{mg} / \mathrm{dl})$ & $4.62 \pm 0.24$ & $3.76 \pm 0.31$ & $4.22 \pm 0.38$ \\
\hline
\end{tabular}

Values are mean $\pm \mathrm{SE} ; \mathrm{n}=6 ; * \mathrm{p}<0.05$ compared to normal animals (Negative control)

Group-I, Healthy control, Group-II Arsenic exposed (NaAsO2 @20mg/kg b.wt orally daily for 45 days),

Group-III Arsenic exposed ( $\mathrm{NaAsO} 2 @ 20 \mathrm{mg} / \mathrm{kg}$ b.wt orally daily) along with AEPG50 for 45 days.

diabetogenic effect of arsenic in chronic arsenic toxicity. The rise of blood glucose might be due to stress condition, which is responsible for the secretion of glucocorticoids from adrenal cortex, which then increases the rate of gluconeogenesis by increasing delivery of amino acids and fats, the gluconeogenic substrates (Kaneko, 1980).

The result of protein estimation of the experiment are presented in Table 1. It was observed that serum protein level gradually decrease non significantly, in group II as compare to control animals. In group III total protein level were restored to normal after treatment. Significant $(\mathrm{P}<0.01)$ decrease in total serum protein was also observed by Biswas et al., (1999) in chronic arsenic toxicity in goats. The decrease protein might be due to increased catabolism because of anorexia.

At the end of the study activity of serum urea nitrogen (SUN) elevated significantly as comparable to control group. In arsenic exposed treated groups the urea nitrogen activity lowered and values reached to normalcy. Similar finding was observed by Nandi et $a l .$, (2005) in chronic arsenic toxicity in rats. Urea is the principal end product of protein catabolism and pathological conditions that reduce the glomerular filtration rate are associated with increased urea in blood (Kaneko, 1980). In Group III values of SUN were normal by the end of the experiment.

The serum creatinine level increased in group II as compared to healthy control rats on $45^{\text {th }}$ day. In the treatment group non significant decrease was observed. Rana et al., (2009) observed significant increase in blood creatinine level in animals exposed to arsenic toxicity through drinking water. Formation of creatinine occurs as a result of muscle metabolism of creatinine and phosphocreatine. Increased level of creatinine indicates alterations in the glomerular filtration, which might be due to chronic renal damage (Kaneko, 1980). AEPG50 was found effective and restore normal values.

The mean serum calcium level decreased in arsenic exposed animals as compared to control group. Serum phosphorus values increased in arsenic toxicity but there was no significant correlation observed in mean phosphorus values. The literature in this regard is very scarce. Psidium guajava treatment brings back the values to normal in group III animals.

The findings of the present study suggest a therapeutic role of $P$. guajava leaves prevent the arsenic induced biochemical alterations. Therefore is concluded that the arsenic exposure led to varying degree of biochemical changes and supplementation of AEPG provide protection due to arsenic in rats.

\section{References}

1. Biswas, S., Talukdar, G and Sharma, A. (1999): Protection against cytotoxic effects of arsenic by dietry supplementation with crude extract of Emblica officinalis fruit. Phyto. Res., 13(6): 513-516.

2. Kaneko, J.J (1980) Clinical biochemistry of domestic animals. ${ }^{\text {rd }}$ Edn. Academic press, New York.

3. Nandi, D., patra, R.C and Swarup, D. (2005): Effect of cystein, methionine, ascorbic acid and thiamine on arsenic induced oxidation stress and biochemical alterations in rats. Toxicol., 211:26-35

4. Pandey, P.K., Nair, S., Bhui, A. and Pandey, M. (2004): Sediment Contamination by Arsenic in Parts of Central-East India and the Analytical Studies on its Mobilisation, Curr. Sci., 86:101-105.

5. Rana, T., Sarkar, S., Mandal, T.K., Batayal, S., Datta, B.K. De, S and Sikdar, S. (2009): Study on the effect of toxicity under highly arsenic prone zone in Nadia district of West Bengal in India. Nature precedings: hdl. 10101/inpre.2009. 2992.1.

6. Roy, M., Pandey, P.K., Roy, S and Chauhan, H.V.S. (2008): Arsenic induced haematobiochemical and histopathological alterations and its level in certain biological samples. Toxicol. Int., 25(1): 57-62.

7. Snedeor, G.W and Cochran, W.G (1994). Statistical methods ( $8^{\text {th }}$ eds). Affiliated East-West Press, New Delhi.

8. Tseng, C.H., Tseng, C.P., Chiou, H.Y., Hsueh, Y.M., Chong, C.K., Chen ,C.J. (2002): Epidemiologic evidence of diabetogenic effect of arsenic. Toxicol Lett., 133:69-76. 